\title{
Analytical study of the reality of cliques ABO incompatibility in newborns at Al- Yarmouk and Al-Kadhimiya teaching hospitals in Baghdad province
}

\author{
Mustafa A.K. Al-Taie; Jabbar H. Yenzeel Al-Hilfy and Nusaibah Amer
}

Department of Biology, College of Science, Baghdad University, Iraq

Accepted on15/12/2011

\section{Summary}

In this study blood samples were collected from 150 newborns (NBs), In a period from 20082010, with blood groups A and B from mother's blood group O positive and those who do not have any other reason for the jaundice.. Of $150 \mathrm{NBs}, 105$ have blood group A and 45 with group B. And the male to female ratio was 1.7:1. The average of NBs age at the onset of jaundice was $19.02 \mathrm{hrs,}$ it was earlier in blood group B and in newborns of first pregnancy. The average of serum bilirubin level at 24 hours was $5.70 \mathrm{mg} / \mathrm{dl}$; there was no statistical value of the blood group and the sex of the NBs in the bilirubin level. Newborns had anemia at delivery in 12 cases, 6 of them were premature. Fifty one NBs were followed for late anemia and found $36(70 \%)$ had anemia. Comparing results between NBs who had anemia and those who had not, found that the bilirubin level was higher in anemic NBs, and they had longer stay in Hospital.

Keywords: ABO incompatibility, Jaundice, Anemia, newborns.

\section{Introduction}

The ABO blood groups incompatibility is common occurrence and often has no significance; it is a medical problem worthy of attention in Iraq. It may, however, cause hematological disease in newborns (1). The ABO blood group incompatibility occurs when the mother blood group type $\mathrm{O}$ and the newborn is either A or B blood group in $40 \%$ of infant, The ABO blood group incompatibility hemolytic disease developments only in $10 \%$ of newborns and the hemolytic disease appeared in about $2 / 3$ cases as disease recorded in the new (1 and 2 ). The hemolytic disease usually occurs from the first pregnancy with a rate of $40-50 \%$ of newborns and it is rear in the following pregnancy (2 and 3 ). The clinical symptoms include $\mathrm{ABO}$ incompatibility cliques that do not usually appear until after the birth as the Jaundice. The basic appearance usually begins during the first 24 hours of life. And as Anemia: hemoglobin levels usually remain within the domain of natural for NBs of the same gestational age, also, anemia could be occur at the age of 8-12 weeks especially when the NBs needs to address the phototherapy or blood transfer (4). Rosen and Geha (4) also reported additional signs, but the magnitude of such is rare liver and spleen. The importance of research to increase the frequency of repulsion cliques $\mathrm{ABO}$ as a cause of hemolytic anemia in NBs born recently, compared with the repulsion $\mathrm{RH}$, which is occurred after the use of Anti D. Requires knowledge of the extent of hemolytic injury and time of the onset of symptoms and severity, as well as follow up the newborns infected to detect any mixing of early or late sign and important of treatment in hospital (4 and 5).

\section{Materials and Methods}

A hundred and fifty NBs at AL-Kadhimiya and Al-Yarmouk Teaching Hospitals who carry blood groups type A or B , born from Opositive mothers. The model of information data include the 150 newborns, rank and time of the start of jaundice and severity of the existence of precedents family history of jaundice at the fraternity. Whole blood from the mother $(5.0 \mathrm{~mL})$ and the baby $(2.0 \mathrm{~mL})$ were collected into separate labeled dry, plain, clean bottles and allowed to clot. After $1 \mathrm{~h}$ standing at room temperature for complete clot retraction, the sera samples were separated after centrifugation at $5000 \mathrm{rpm}$ for $10 \mathrm{~min}$. The sera samples were stored at $-20^{\circ} \mathrm{C}$, while the red cells were stored at $4^{\circ} \mathrm{C}$ until the time of analysis. Laboratory study was to conduct hemoglobin at 24 and 48 hours after a month 
and two months, as well as a study of the Bilirubin at 24 hours and 48 hours.

Direct Coomb's Test (DCT) was done on the babies' cells according to the method of (6). $\mathrm{ABO}$ cells and serum grouping were done on the mothers' and the babies' samples according to the methods of (7). Antibodies detection and quantization were done on the mothers' serum samples according to the method of (8 and 9).

\section{Results and Discussion}

The total 150 NBs included in present work persons carry blood group A or B and their mothers' the entire group $\mathrm{O}$ - positive. The percentage of ABO Incompatibility was $12 \%$ of all pregnancies. Total NBs form group A was $105(70 \%)$ of all NBs and group B 45 was $30 \%$ (Table, 1).

Table, 1: The distribution of newborns according to their blood Group

\begin{tabular}{|rrr|}
\hline Group A & 105 & $\mathbf{7 0 \%}$ \\
\hline Group B & 45 & $30 \%$ \\
\hline
\end{tabular}

The number of males NBs was 96 (64\%) were distributed across the study as follows: Blood group A was found in blood of 61 and group B in $35 \mathrm{NBs}$. The number of females was 54 NBs divided as follows: Blood group A was found in 44 and group B in $10 \mathrm{NBs}$. While the male to female ratio was 1:1.7 (table, 2).

Table, 2: The distribution of newborns according to Newborn blood groups and sex ratio

\begin{tabular}{|c|ccc|c|}
\hline Sex & Number & $\%$ & $\begin{array}{c}\text { A } \\
\text { group }\end{array}$ & $\begin{array}{c}\text { B } \\
\text { group }\end{array}$ \\
\hline Male & $\mathbf{9 6}$ & $\mathbf{6 4 \%}$ & $\mathbf{6 1}$ & 35 \\
\hline Female & $\mathbf{5 4}$ & $\mathbf{3 6} \%$ & $\mathbf{4 4}$ & 10 \\
\hline
\end{tabular}

The 150 NBs were included in present study, of them $67(44.5 \%)$ were got from the first pregnancy, and the other $83(55.5 \%)$ NBs was obtained from a previous pregnancy in included 18 cases from abortion (table, 3 ).

Table, 3: The distribution of newborns in order of pregnancy

\begin{tabular}{|ccc|}
\hline Order Number & Number & $\begin{array}{c}\text { Percentage } \\
\text { of } \\
\text { pregnancy }\end{array}$ \\
\hline First pregnancy & $\mathbf{6 7}$ & $\mathbf{4 4 . 5 \%}$ \\
\hline $\begin{array}{c}\text { Previous } \\
\text { pregnancies }\end{array}$ & $\mathbf{8 3}$ & $\mathbf{5 5 . 5 \%}$ \\
\hline
\end{tabular}

The totals of $130(87 \%)$ cases were obtained from normal pregnancy and $20(13 \%)$ from premature abortions, (table 4).

Table 4: The distribution of newborns according to age

\begin{tabular}{|lcc|}
\hline Age of pregnancy & Number & $\begin{array}{c}\text { Number } \\
\text { Percentage }\end{array}$ \\
\hline Normal pregnancy & $\mathbf{1 3 0}$ & $\mathbf{8 7 \%}$ \\
\hline Premature & $\mathbf{2 0}$ & $\mathbf{1 3 \%}$ \\
\hline
\end{tabular}

History of the brothers with jaundice observed in $22(14.6 \%)$ cases with unknown causes about the jaundice in siblings. Nine of those NBs were treated with a light phototherapy, other 9 cases were treated by replacement of blood, while $4(2.6 \%)$ cases was not curable, (table,5).

Table, 5: The history of jaundice in newborns brothers

\begin{tabular}{|c|c|c|c|}
\hline \multicolumn{3}{|c|}{ Number } & Percentage \\
\hline No famil & history & 128 & $85.4 \%$ \\
\hline \multirow{3}{*}{$\begin{array}{l}\text { Positive family } \\
\text { history }\end{array}$} & $\begin{array}{c}\text { Replacement } \\
\text { of blood }\end{array}$ & 9 & $6 \%$ \\
\hline & Phototherapy & 9 & $6 \%$ \\
\hline & No Hospitals & 4 & $2.6 \%$ \\
\hline
\end{tabular}

Laboratory coombs tests was performed directly in 131 NBs only $11(8.5 \%)$ showed a positive, while the indirect coombs test was negative in all tested NBs. as shown in Table-6. Table, 6: Combs built the test result- immunity test

\begin{tabular}{|ccc|}
\hline $\begin{array}{c}\text { Direct } \\
\text { Coombs } \\
\text { test }\end{array}$ & Number & Percentage \\
\hline $\begin{array}{c}\text { positive } \\
\text { Negative }\end{array}$ & $\mathbf{1 1}$ & $\mathbf{8 . 5 \%}$ \\
\hline
\end{tabular}

Bilirubin in serum of the NBs was noted and jaundice was happened in recently NBs in varying ages, started in the first 24 hours of life in 99 cases ( $66 \%$ ), while the jaundice was appeared in $10(6.6 \%)$ after 24 to 48 hours of age and found in $41(27.45 \%)$ cases of older age (table, 7 ).

Table, 7: The time of jaundice appearance in newborns

\begin{tabular}{|ccc|}
\hline Start time & Number & Ratio \\
\hline$>\mathbf{2 4}$ hours & 99 & $\mathbf{6 6 \%}$ \\
\hline $\mathbf{2 4}$ to 48 hours & $\mathbf{1 0}$ & $\mathbf{6 . 6 \%}$ \\
\hline$<\mathbf{4 8}$ hours & $\mathbf{4 1}$ & $\mathbf{2 7 . 8 \%}$ \\
\hline
\end{tabular}


The average age of newborns at the start of jaundice was 19 hours. The average age was $21.5 \mathrm{hrs}$ recorded in NBs carrying blood group type A while group B Showed jaundice earlier at $13.7 \mathrm{hrs}$. Applying the test of the difference between the average combined, find that $\mathrm{Z}=$ 6.61 and statistical significant $(\mathrm{P}<0.05)$ difference. Other workers (10) also, was recorded the average age of NBs was $28 \mathrm{hrs}$ in group B and first pregnancy. Compare the time of the start of jaundice in terms of sex, the average age of males NBs was 18.44 hrs while in female was $20.13 \mathrm{hrs}$, no statistically differences was found.

Studied the effect of pregnancy order on the time of the jaundice start, the two groups of newborns were taken from the first pregnancy as A group and NBs from multiple pregnancies previous group (whether pregnancies natural or abortions) as B group. The results indicated that the average age of the NBs of the first pregnancy was $17 \mathrm{hrs}$ compared to 20.12 of the other group, no statistical difference was found. While the mean average values of bilirubin two groups of NBs in the first 24 hours of life was $5.30 \mathrm{mg} / \mathrm{dl}$. The average value in blood of NBs carrying group A was $5.7 \mathrm{mg} / \mathrm{dl}$ and $5.8 \mathrm{mg} / \mathrm{dl}$ in group B. Test the difference between the averages combined did not find a statistical differences. Also, there were no differences during first $24 \mathrm{hrs}$ of life between male and female NBs in the average values of bilirubin. While the impact of brothers history of jaundice which raise the values of bilirubin, compared between the recently NBs who have a history of brothers jaundice, appeared with the average of was $6 \mathrm{mg} / \mathrm{dL}$, while the NBs with no brothers history of jaundice had the value of bilirubin $5.81 \mathrm{mg} / \mathrm{dl}$, no statistically difference was found.

The existence of appositive family with jaundice history when the brothers in 22 cases (14\%), it did not find any effect of the existence of precedents in raising the values of bilirubin (12). Present work did not find any role for the pregnancy in order to influence the severity of high bilirubin in NBs, and this is supported not exacerbate the severity of hemolysis cascade pregnancies. While the factors that may have an impact on the duration of Hospitalization did not find any significant factor like blood groups or sex or gestational period on the impact on the number of days of Hospitalization.

Hemoglobin measurement has been monitoring to $51 \mathrm{NBs}$ aged 24, $48 \mathrm{hrs,}$, month and 2 months after birth. The average values of hemoglobin in NBs at 24 hours was $12.7 \mathrm{~g} / \mathrm{dl}$, $12(8 \%)$ had anemia at 24 hours (including 6 preterm infant, Premature) of them, $6 \mathrm{NBs}$ obtained from the first pregnancy and 6 from the multiple pregnancies. While the average hemoglobin values after 48-hour was $14 \mathrm{~g} / \mathrm{dl}$. And the average of the low hemoglobin was recorded at the ages of 24-48 hrs was $1.15 \mathrm{~g} /$ dl. The application of statistical study to examine the effect of blood groups on the rate of hemoglobin decline, found that the average decline in hemoglobin in group A was $1.1 \mathrm{~g} / \mathrm{dl}$ and $1.28 \mathrm{~g} / \mathrm{dl}$ in group $\mathrm{B}$, no statistical differences was found. While the measurement of the hemoglobin values at month and two months of age in $51 \mathrm{NBs}$, anemia was recorded in $36(70.5 \%)$ NBs only.

The percentage of hemolysis in 67 cases was $44.5 \%$ occurred in the first pregnancy and it is not necessary to have a history of pregnancies of abortion to hemolysis happen (11). Anemia was found in 29 males $(56.8 \%)$ and $22(43.2 \%)$ females NBs, male to female ratio was $1: 1.3$ which is close to the proportion of the overall study (1:1.7). Anemia was observed in $38 \mathrm{NBs}$ of blood group $\mathrm{A}$ and 13 NBs group B. As well as in 19 NBs $(37.2 \%)$ from first pregnancy and $32 \mathrm{NBs}(62.7 \%)$ of previous pregnancies similarly, no statistical difference between the previous groups was found. Tiker et al., (10) reported in 136 Turkish NBs the level of hemoglobion and bilirubin of incompatibility $\mathrm{ABO}$ was $14.8 \%$ this percentage is close to present study.

The average days of Hospitalization in normal recently NBs not develop anemia was 2.5 days, while the average days of Hospitalization in NBs who happened to have anemia late was 4 days with statistically significant $(\mathrm{P}<0.05)$ differences between the two groups, this supports the previous result which showed that the numbers of NBs showed bilirubin were higher in the of previous pregnancies.

The average values of hemoglobin in NBs that happened to have anemia two months of age was $9 \mathrm{~g} / \mathrm{dl}$. The number of newborns 
recently who required Hospitalization 48 states together (32\%), and this percentage is relatively high compared with rates of other causes of Hospitalization. This indicated that the importance of the repulsion cliques $\mathrm{ABO}$ as a cause important to the Hospital when the newborns born recently, and to examine factors that may have a role to Hospitalization. Present study did not find significant differences for the newborn blood groups, or pregnancy in order to increase the proportion of Hospitalization.

Study of hemoglobin during the first 24 hours and 48 hours was observed anemia only in 12 cases ( $8 \%$ ), and the values of hemoglobin close to normal in the remaining cases, this refers to the fact that anemia mark is not common in the repulsion cliques $\mathrm{ABO}$, and perhaps this is due to weak capacity antigenic total factors $\operatorname{ABO}(13,14,15$ and 16). The rate of decline in hemoglobin between the ages of 24-48 hours is $1.1 \mathrm{~g} / \mathrm{dl}$ did not find any role for the clique blood or sex of newborn or order

\section{References}

1. http://www..pregnancy.com.au/resources/t opics-of-interest/postnatal/aboincompa tibility-in-newborns.html (2003). 18 July 2003.

2. Behrman, R.; Kleigman, R., and Jenxon, H. (2000). Nelson text book of pediatrics, $16^{\text {th }}$ ed., W.B. Saunders Company, USA, P: 2618.

3. Bonne, H. (1988). Medicine perinatale, Simep,

4. Rosen, F. and Geha, R. (2011). Case Studies in Immunology, $4^{\text {th }}$ ed., Garland Sci., P: 173.

5. Coombs, R.R.; Mourant, A.E. and Race, R.R. (1945). A new test for the detection of weak and "incomplete" Rh agglutinins. Brit. J. Exp. Path., 26:255-266.

6. Knowles, S.M. (2001). Laboratory aspects of blood transfusion. In: Lewis SM, Bain BJ, Bates I, editors. Dacie and Lewis: Practical Hematology. $9^{\text {th }}$ Ed. New York: Churchill Livingstone PP: 487-490

7. Knowles, S.M. (2001). Laboratory aspects of blood transfusion. In: Lewis, S.M.; Bain, B.J. and Bates, I. editors. Dacie and Lewis: Practical Haematology. $9^{\text {th }}$ Ed. New York: Churchill Livingstone, PP: 471-476. of pregnancy in effect on the rate of decline in hemoglobin, and the study of anemia late been a hemoglobin age of one month and two months at 51. Newborns were noted anemia in 36 late Newborns $(70 \%)$ and a high percentage refers to the importance of follow-up to the fact that hemoglobin anemia occurs late was relatively high (17, 18 and 19). The males NBs were likely to have anemia with ratio of $1: 1.3$ to female, indicated that males were more likely to anemic late, and the males peak values of bilirubin was $13.1 \mathrm{mg} / \mathrm{dl}$ higher than the rest of the newborns. The duration of hospitalization have longer than the rest of the recent newborns and this refers to the need for follow-up of newborns who had high bilirubin as accuse for anemia. Blood transfusion was performed in 6 cases $(17 \%), 4$ of them were obtained from aborted cases which were more premature and need for blood transfusions (20, 21 and 22).

8. Knowles, S.M. (2001). Red cell antigens and antibodies, erythrocytes, platelets and granulocytes In: Lewis, S.M., Bain, B.J. and Bates, I. editors. Dacie and Lewis: Practical Haematology. $9^{\text {th }}$ Ed. New York: Churchill Livingstone, PP: 451-453.

9. Regan, F., Newlands, M. and Barbara, J.M. (2001). Acquired hemolytic anemia's. In: Lewis S.M.; Bain, B.J. and Bates, I., editors. Dacie and Lewis: Practical Hematology. $9^{\text {th }}$ Ed. New York: Churchill Livingstone, P: 215.

10. Tiker, F.; Gürakan, B.; Tarcan, A. and Özbek, N. (2006). Fatal course of ABO hemolytic disease associated with hydrops in a twin pregnancy. Turk J Pediat, 48: 7375.

11. Fabien, G. and Ekarine, Z. (1999). Neonatology management procedures diseases and drugs, $4^{\text {th }}$ ed. MCGRAWHILL Com., P: 698.

12. Hay, W.; Hayward, A.; Levin, M. and Sondhimer, J. (2001). Current pediatric diagnosis and treatment. $15^{\text {th }}$ Ed. Lange Medical Books McGrawhill, USA, $\mathrm{P}: 1255$.

13. Johnson, L.H.; Bhutani, V.K. and Brown, A.K. (2002). System-based approach to management of neonatal jaundice and 
prevention of kernicterus. J. Pediat., 140:396-403.

14. Katz, M.A; Kanto, W.P. and Koratkin, J.H. (1982). Recurrence rate of $\mathrm{ABO}$ hemolytic disease of the newborn. Obstet. Gynecol., PP: 611-614.

15. Ziqursky, A. and Bowman, J.M. (1993). Isoimmune hemolytic disease, $4^{\text {th }}$ ed. Philadphapa: WB Saunder, PP: 44-74.

16. Davidsohni ABO (1956). Incompatibility as a cause of hemolytic disease of the newborn. Obstet. Gynecol. Sep., 8(3):318-322.

17. Robinson, G.C.; Phillips, R.M. and Prystowsky, M. (1951). Spherocytosis and increased fragility occurring in erythroblastosis fetalis associated with ABO incompatibility. Pediatrics, 7(2): 164-171.

18. Rosenfield, R.E. (1955). A-B Hemolytic disease of the newborn; analysis of 1480 cord blood specimens, with special reference to the direct antiglobulin test and to the group O mother. Blood, 10(1): 17-28.

19. Unger, L.J. and Wiener, A.S. (1954). Studies on the $\mathrm{C}$ antibody of group $\mathrm{O}$ serum with special reference to its role in hemolytic disease of the newborn. J. Lab. Clin. Med., 44(3):387-399.

20. Levien, D.H and Meyer, H.B. (2000). Newborn screening for ABO hemolytic disease, Clin. Pediat., 74:391-394

21. Koenig, J.M. (2000). Evaluation and treatment of erythroblastosis fetalis in the neonate. In: Christensen, R.D. (ed). Hematologic Problems of the Neonate. Philadelphia, WB Saunders, PP: 185-207.

22. Sarici, S.U., Yurdakok, M. and Serdar M.A. (2002). An early (sixth hour) pserum bilirubin measurement is useful in predicting the development of significant hyperbilirubinemia and severe $\mathrm{ABO}$ hemolytic disease in a selective high risk population of newborns with $\mathrm{ABO}$ incompatibility. Pediat., 109: 53- 60.

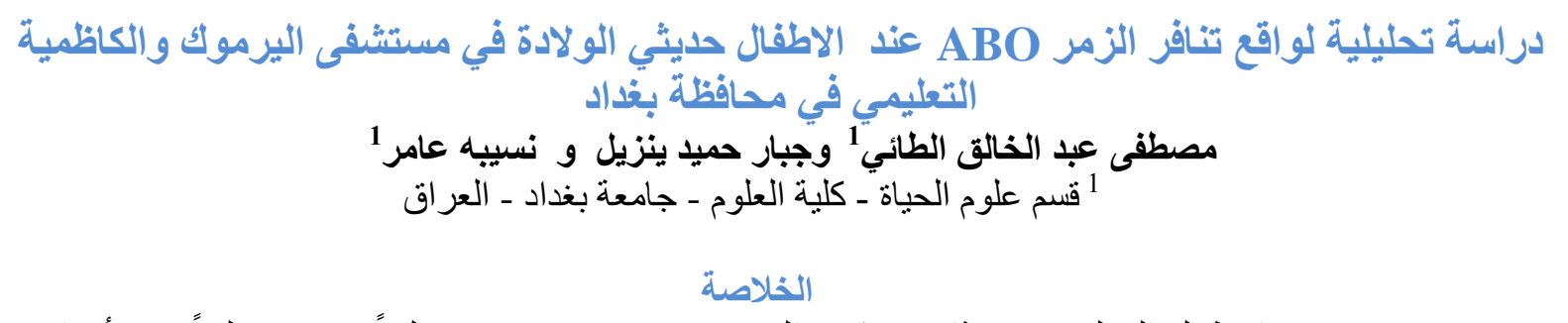

جمعت 150 عينه من الاطفال المولودين حديثا من ذوي الزمرة A A A A A 105 وليداً، 45 B وليداً]من أمهات زمرة

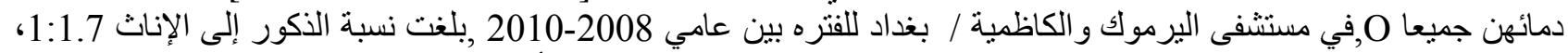

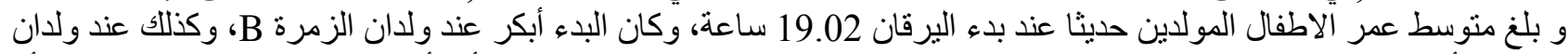

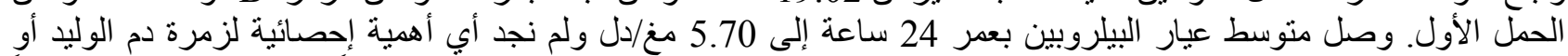

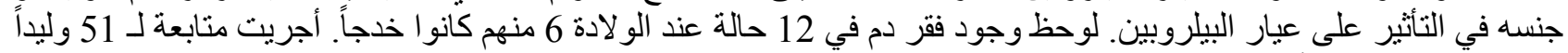

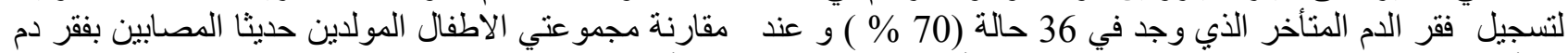

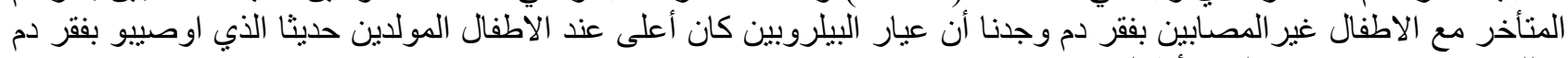
كذلك كانت مدة الاسنشفاء لايهم أطول. 